\title{
SOSOK PRESIDEN JOKO WIDODO DALAM PEMBERITAAN TENTANG KABINET KERJA
}

\author{
Fanny Lesmana $^{*}$, Aylanda Dwi Nugroho ${ }^{2}$, Desi Yoanita ${ }^{3}$ \\ ${ }^{1,3}$ Fakultas Ilmu Komunikasi, Universitas Kristen Petra, Surabaya \\ ${ }^{2}$ Fakultas Sastra, Universitas Kristen Petra, Surabaya \\ * Penulis korespondensi; Email: flesmana@petra.ac.id
}

\begin{abstract}
ABSTRAK
Kabinet merupakan hal yang krusial dalam sebuah pemerintahan. Dalam menjalankan kinerja pemerintahan, Presiden Republik Indonesia, Joko Widodo, juga membutuhkan pembantu yakni para menteri yang tergabung dalam sebuah kabinet yang disebut Kabinet Kerja. Media televisi merupakan salah satu media massa yang dianggap memberikan pengaruh pada opini publik. Dengan menggunakan metode analisis framing Gamson dan Modigliani, peneliti melihat bagaimana Metro TV dan TVOne memberitakan sosok Presiden Joko Widodo terkait dengan kabinet yang dipimpinnya. Temuan penelitian menunjukkan Metro TV cenderung membingkai sosok Joko Widodo sebagai presiden dengan menunjukkan kebijakan dan prinsip yang dimilikinya. Sebaliknya, tvOne membingkai Joko Widodo sebagai presiden yang tidak konsisten dan tidak pro rakyat.
\end{abstract}

Kata kunci: Berita, televisi, Joko Widodo, kabinet, analisis framing.

\begin{abstract}
Cabinet is a crucial in a government. In carrying out the government's performance, President of Republik Indonesia, Joko Widodo, also need a several ministers who called Kabinet Kerja. Television is one of the mass media that can provide influence on public opinion. Using framing analysis Gamson dan Modigliani, authors look at how the Metro TV dan TVOne making a news about President Joko Widodo and Kabinet Kerja. The findings show that Metro TV tends to frame the figure of Joko Widodo as a president by pointing out his policies and principels. Instead, tvOne framed Joko Widodo as an inconsistent president and pro on the people.
\end{abstract}

Keywords: News, television, Joko Widodo, cabinet, framing analysis.

\section{PENDAHULUAN}

Menurut Itule dan Andn (2000, hal. 10), berita merupakan istilah yang sangat kompleks. Berita adalah sebuah informasi, dan pada saat ini berita adalah informasi bisnis. Apa yang menjadi berita pada hari ini mungkin bukanlah berita pada hari mendatang. Apa yang menjadi pada satu daerah tertentu bisa jadi bukanlah berita di tempat yang lain. Namun, yang terpenting dari sebuah berita adalah berita selalu berubah.

Berita dibagi menjadi dua bentuk yaitu hard news dan soft news. Yang termasuk dalam hard news adalah peristiwa pembunuhan, pertemuan dewan kota juga pidato pemimpin daerah. Peristiwa tentang situasi kabinet dalam pemerintahan terlasu juga dalam hard news.

Pembaca suratkabar, penonton televisi dan pendengar radio sangat tertarik pada peristiwa-peristiwa lokal. Segala sesuatu yang terjadi di kota mereka merupa- kan hal yang menarik untuk diketahui. Segala sesuatu yang terjadi di kota mereka merupakan hal yang menarik untuk diketahui. Salah satu yang menarik untuk diketahui adalah peristiwa tentang politik (Mencher, 2000, hal. 598). Berita tentang pemilihan anggota kabinet merupakan salah satu peristiwa politik yang cukup menarik minat audiens. Pada pemberitaan hal seperti ini, maka publik ikut memberikan opini dan seperti yang telah disebutkan oleh Itule dan Anderson, berita saat ini telah menjadi bisnis informasi.

Tak dapat dipungkiri, industri media juga telah berorientasi pada bisnis. Mosco (dalam Wicaksono, 2015, hal. 2) mengidentifikasi bahwa dalam praktik media telah mengalami komodifikasi. Selanjutnya, keberadaan media massa di bawah kekuasaan modal seperti ini juga diperparah dengan praktik oligrakhi politik di Indonesia. Karenanya, tak mengherankan bila peran media massa sebagai pilar keempat demokrasi mengalami masalah. Fungsi informasi dan pengawasan menjadi terganggu. 
Harahap (2013: 45) menegaskan bahwa tidak ada media yang mampu menjaga eksistensinya tanpa modal yang kuat. Bagaimana pun, modal yang kuat akan memungkinkan media lebih mudah dalam mewujudkan misinya di hadapan publik. Masih dalam buku yang sama, Fabozzi menegaskan bahwa modal yang ditanamkan oleh individu atau kelompok memiliki kewenangan dalam mengatur mekanisme kerja sebuah perusahaan. Dalam hal perusahaan media, demikian pula adanya.

Di dalam buku Media Darling ala Jokowi, Wulandari (2014: 108-109) mengutip pernyataan Brian McNair yang ditulis dalam Sudibyo (2001:2-5) terkait ideologi media. Menurut McNair, secara teoritis, ideologi media dapat dibedah tiga pendekatan, yakni pendekatan politik ekonomi, pendekatan organisasi, dan pendekatan kultural. Dari ketiga pendekatan itu, pendekatan kultural yang dianggap paling memadai untuk menganalisis isi media karena menggabungkan pendekatan ekonomi politik dan organisasi. Dalam pendekatan ini, dapat dilihat bahwa produksi sebuah berita tidak saja diwarnai perdebatan seru para wartawan maupun redaktur, tetapi bisa juga terjadi karena adanya intervensi pemilik atau orang ketiga yang mewakili dunia luar dengan segala dinamikanya.

Siregar (dalam Wicaksono, 2015, hal. 3) menegaskan bahwa riset yang telah dilakukan oleh Dewan Pers dan Perkumpulan Masyarakat Peduli Media, PR2 Media dan Remotivi pada tahun 2013 menyimpulkan bahwa intervensi pemilik terlihat sangat vulgar. Media massa yang dimiliki oleh pimpinan partai politik menunjukkan kecenderungan tidak netral dan tidak independen dalam pemberitaannya.

tvOne dan MetroTV merupakan dua stasiun televisi swasta dengan kepemilikan yang berbeda. tvOne memiliki tagline tvOne Memang Beda (www. tvonenews.tv). Stasiun televisi ini didirikan pada tahun 2008 dengan penggagas utama yaitu Aburizal Bakrie dan Erick Thohir. Komposisi kepemilikan saham tvOne terdiri dari PT Visi Media Asia Tbk sebesar 49 persen. Direktur utama dari perusahaan ini adalah Anindya N. Bakrie, putra Aburizal Bakrie (CNN Indonesia, 18 April 2015). Sisanya dipegang oleh beberapa perusahaan. Direktur utama tvOne saat ini adalah Ardiansyah Bakrie yang merupakan putra Aburizal Bakrie lainnya.

Sejak tahun 2009, Aburizal Bakrie (Ical atau ARB) menjabat sebagai Ketua Umum Partai Golongan Karya (Golkar). Diketahui pada pemilihan umum presiden RI tahun 2014, ARB memutuskan untuk maju sebagai calon presiden dari Partai Golkar (profil. merdeka.com) . Namun, hal itu tidak berjalan mulus. Partai Golkar sendiri - di bawah kepemimpinan ARB - akhirnya memutuskan untuk bergabung dengan Koalisi Merah Putih yang bertujuan untuk memenangkan pasangan Prabowo-Hatta sebagai Presiden dan Wakil Presiden RI dalam Pemilu 2014.

Di sisi lain, MetroTV dimiliki oleh Surya Paloh yang merupakan pendiri dari Partai Nasional Demokrat (Nasdem). Dalam pemilihan umum Presiden RI tahun 2014, Partai Nasdem memutuskan untuk berada pada kubu KIH (Koalisi Indonesia Hebat), dimana pada koalisi ini dimotori oleh Partai Demokrasi Indonesia Perjuangan (PDI-P). Meskipun sempat mencalonkan diri sebagai Presiden RI pada pemilu 2014, namun langkah Surya Paloh terhenti. Meski demikian, Surya Paloh bersama Partai Nasdemnya memilih untuk menempatkan kakinya pada Koalisi Indonesia Hebat $(\mathrm{KIH})$. Yang menarik saat memperebutkan kursi calon presiden pada Munas Golkar 2009, Surya Paloh sebagai pemilik Harian Media Indonesia dan stasiun televisi MetroTV, menyatakan bahwa ia mengarahkan kedua media massa itu untuk membantunya (Harsono, 2010, hal. 170).

Masih dalam kaitan dengan pemilihan umum Presiden RI tahun 2014, tribunnews.com (4 Juli 2014) mengunggah berita perihal kecaman anggota DPR RI terhadap praktik pemberitaan stasiun televisi tvOne yang dinilai jauh dari praktik jurnalistik akibat intervensi pemilik modal yang dianggap berlebihan.

Dalam hal konstelasi politik, kedua pemilik saham terbesar dari masing-masing stasiun televisi swasta ini menunjukkan ketidaksepahaman sikap. Berkaca dari apa yang dipikirkan oleh Mosco bahwa media massa mengalami komodifikasi dalam perjalanan ideologinya, hal yang sama sangat mungkin terjadi pada kedua stasiun televisi swasta ini.

Sebuah peristiwa dianggap layak diberitakan jika memiliki nilai berita. Ishwara (2005, hal. 53) menyatakan bahwa nilai berita merupakan sebuah ukuran untuk menyatakan apakah sebuah peristiwa layak diberitakan atau tidak. Pemberitaan tentang bidang politik memiliki nilai berita signifikan maupun kedekatan karena berkaitan dengan kepentigan orang banyak, dalam hal ini adalah suatu negara. Karenanya pemberitaan tentang pemilihan kepala negara tidak bisa diabaikan oleh media massa dari negara mana pun, termasuk Indonesia.

Di dalam konteks pemilihan kepala negara - termasuk di antaranya adalah pembentukan kabinet 
dalam sebuah pemerintahan - akan terlihat adanya konflik atau ketegangan. Selain itu, kedekatan (proximity) yang juga merupakan hal penting dalam sebuah berita juga nampak dalam pemberitaan bidang politik. Tak dapat dipungkiri, pemberitaan tentang politik adalah hal yang sangat penting karena menyangkit sebuah konsekuensi tidak hanya di negara itu sendiri, melainkan juga dengan negaranegara tetangga maupun pemerintahan negara lain di seluruh dunia.

Pembentukan Kabinet Kerja yang menggawangi kinerja pemerintahan Presiden Joko Widodo dan Wakil Presiden Jusuf Kalla telah mengalami kasak kusuk sejak awal pembentukannya. Hal ini tidak dapat dihindarkan karena pencalonan Joko Widodo sebagai presiden pada Pemilu 2014 juga sempat menjadi kontroversi. Seeperti yang disampaikan oleh Guruh Soekarno Putra yang merupakan kader PDIP. Ia menilai bahwa Joko Widodo belum siap menjadi calon presiden (https://www.youtube.com/watch ?=_1W_V1k8BPY).

Dalam penelitian ini, penulis hendak melihat apa yang sedang dibingkai oleh masing-masing stasiun televisi swasta dalam hal menggambarkan sosok Joko Widodo sebagai Presiden Republik Indonesia, khususnya dalam kaitan dengan Kabinet Kerja yang dipimpinnya.

\section{METODE PENELITIAN}

Dalam konteks penelitian pemberitaan terkait Presiden Joko Widodo dengan Kabinet Kerja, sebagai pembantu dalam menjalankan kinerja serta programnya, penulis melihat bagaimana berita tentang hal tersebut disampaikan oleh dua stasiun televisi swasta, yakni Metro TV dan tvOne. Penulis membedah beberapa berita yang disampaikan oleh kedua stasiun televisi ini dengan menggunakan analisis framing model Gamson dan Modigliani.

Dalam metode ini terdapat dua perangkat yaitu framing devices (perangkat framing) yang meliputi methapors, catchphrases, exemplaar, depiction, dan visual images; serta reasoning devices (perangkat penalaran) yang meliputi roots, appeals to principle, dan consequences. Kedua perangkat ini akan dipergunakan untuk melihat hal apa yang menjadi bingkai dari setiap stasiun televisi.

Sumber data yang dipergunakan dalam penelitian ini adalah berita tentang Kabinet Kerja yang ditayangkan oleh Metro TV maupun tvOne sejak diumumkannya
Kabinet Kerja hingga pelaksanaan kerja. Namun, penelitian ini dibatasi hingga bulan Juni 2015 saja. Berikut adalah berita yang dianalisis:

\begin{tabular}{l|l}
\hline \multicolumn{1}{c|}{ MetroTV } & \multicolumn{1}{c}{ TVOne } \\
\hline Bagaimana komposisi & Jokowi Menolak Rencana \\
profesional dan partai & Pengadaan Mobil Dinas \\
yang ideal & $\begin{array}{l}\text { Baru Menteri Kabinet } \\
\text { Kerja }\end{array}$ \\
Apakah kabinet & $\begin{array}{l}\text { Kabinet Jokowi Tersan- } \\
\text { dera Parpol }\end{array}$ \\
\hline
\end{tabular}

Peneliti mengumpulkan data dari video yang diunggah melalui situs youtube.com yang dicari berdasarkan kata kunci KABINET.

\section{PEMBAHASAN}

Kabinet Kerja yang dibentuk oleh Presiden Joko Widodo dan Wakil Presiden Jusuf Kalla terdiri dari 4 menteri koordinator dan 30 menteri. Pengumuman nama-nama menteri Kabinet Kerja disampaikan oleh Presiden Joko Widodo melalui beberapa stasiun televisi secara live pada 26 Oktober 2014.

Dalam kinerjanya, Joko Widodo melakukan pergantian menteri (reshuffle) pada Kabinet Kerja yang diumumkan pada 12 Agustus 2015. Ada enam menteri yang diganti pada proses reshuffle ini. Hanya saja peneliti tidak melihat hal-hal yang terkait pada proses reshuffle karena penelitian hanya dibatasi hingga bulan Juni 2015 saja.

\subsection{Berita di MetroTV}

1) Berita 1-bagaimana komposisi profesional dan partai yang ideal

Dianalisis menggunakan perangkat framing milik Gamson dan Modigliani, ada beberapa kata maupun kalimat yang cukup signifikan untuk dikaji dalam pemberitaan ini. Penyiar Metro TV menyebutkan kalimat: Joko Widodo menyambut baik usulan dari para relawan meski memiliki kriteria sendiri untuk menempatkan orang pilihan di kabinetnya.

Pada kalimat tersebut terdapat catchphrases 'menyambut baik usulan'. Sepertinya Metro TV ingin menunjukkan bahwa Joko Widodo sebagai Presiden merupakan sosok yang bijaksana dalam menyikapi setiap masukan di sekitarnya. Hal ini dianggap penting bagi Metro TV dalam menonjolkan cerminan sosok presiden yang mengayomi hal apa pun yang sedang bergerak dalam masyarakat. 


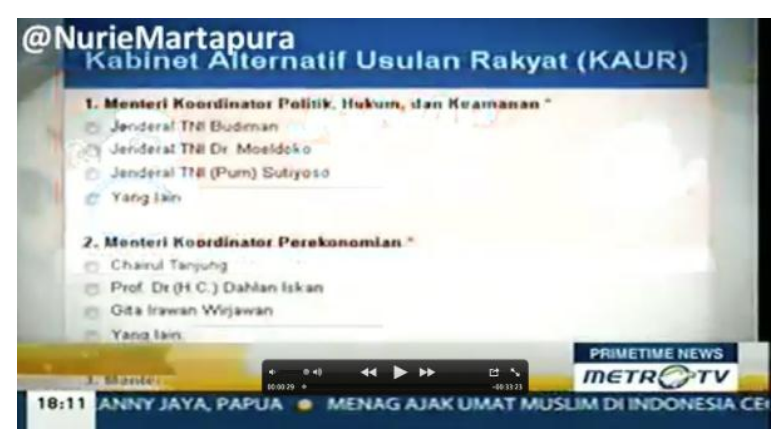

Gambar 1. Tampilan akun Facebook relawan Jokowi yang membuat poling pada masyarakat untuk memberikan usulan nama calon menteri Kabinet Joko Widodo-Jusuf Kalla (sumber: youtube.com)

Gambar di atas mendukung pembingkaian berita secara keseluruhan bahwa Joko Widodo dengan bijaksana tidak menolak adanya kreativitas yang dilakukan pendukungnya dalam mencari dan menemukan nama-nama calon menteri dalam kabinetnya kelak.

Pembingkaian sosok Joko Widodo sebagai presiden yang berprinsip juga nampak pada kalimat di atas yang menunjukkan Joko Widodo memiliki kriteria tersendiri dalam menentukan calon menterinya.

Tercermin pula sosok yang berprinsip ini pada kalimat yang diucapkan oleh VO bahwa:

Joko Widodo memang belum banyak berkometar soal nama orang yang akan duduk di kabinetnya. Namun mantan Wali Kota Solo ini mengatakan orang yang masuk dalam kabinetnya haruslah profesional, bersih dan paham administrasi pemerintahan.

Dengan perangkat exemplaar, terlihat Metro TV berupaya mengingatkan pada pemirsa bahwa Joko Widodo adalah mantan Wali Kota Solo yang pernah dikagumi oleh banyak orang - khususnya warga Solo - dalam mengemban amanat sebagai abdi negara yang bersih dan profesional.

Terbingkainya sosok Joko Widodo sebagai Presiden yang bijak dan berprinsip ini dipungkas oleh Metro TV melalui pernyataan VO:

Jokowi dan JK dalam sebuah kesempatan mengatakan bahwa pembentukan kabinet didasari dari kebutuhan yang ada dan tidak didasari oleh prinsip bagi-bagi kekuasaan terhadap parpolparpol pendukung mereka.

Berdasar perangkat appeals to principle (klaim moral), berita ini seolah ingin menegaskan pada pemirsa televisi bahwa dalam pemilihan calon menteri tidak ada prinsip bagi kekuasaan, melainkan lebih didasarkan pada prinsip kebutuhan.

\section{2) Berita 2 - Apakah kabinet Jokowi Dirombak?}

Dalam berita ini, presenter 1 menyatakan kalimat: Isu reshuffle kabinet atau perombakan kabinet Jokowi JK dibantai istana dan sekretaris kabinet.

Ada dua catchphrases dalam kalimat ini. Yang pertama adalah isu. Yang kedua adalah dibantai. Kata isu menunjukkan bahwa kabar itu bukanlah situasi yang sebenarnya, melainkan hanya merupakan kabar burung saja. Metro TV seperti ingin menampik kabar tersebut dan meluruskan kabar burung itu.

Pemilihan kata dibantai merupakan hal yang berbeda dengan kata dibantah. Umumnya, jika hendak menolak suatu pernyataan, maka digunakan kata membantah. Namun dalam berita ini, kata dibantai yang dipilih seolah ingin menunjukkan bahwa isu tersebut benar-benar salah sehingga harus dihabisi hingga ke akar-akarnya.

Dua kali disebutkan oleh Metro TV bahwa adanya pihak yang menganggap kebijakan beberapa menteri tidak sinkron dengan keinginan Presiden Joko Widodo hendak menunjukkan bingkai bahwa wacana perombakan kabinet ini dilontarkan oleh pihak-pihak yang tidak pro terhadap pemerintahan Joko Widodo sebagai presiden.

Metro TV ingin menunjukkan sikap Joko Widodo yang memiliki prinsip melalui klaim-klaim moral melalui beberapa pernyataan di bawah ini:

- Namun Pratikno tidak membantah pemerintah akan terus mengevaluasi kinerja setiap menteri setiap saat

- ... dalam rapat terbatas maupun rapat paripurna kabinet, Presiden Joko Widodo kerap melakukan evaluasi langsung pada para menteri. Evaluasi tersebut menyangkut pencapaian target oleh kementrian, serapan anggaran hingga pemberitaan oleh media...

- Sejak awal Jokowi menegaskan tidak segan merombak kabinet jika para menteri tidak bekerja sesuai dengan target.

Tidak segannya Joko Widodo dalam melakukan perombakan kabinet ingin ditegaskan oleh Metro TV bahwa Joko Widodo adalah sosok yang memiliki prinsip dalam sebagai pemimpin walaupun belum ada wacana perombakan kabinet. 
Pemilihan gambar Joko Widodo dengan tulisan Presiden Terpilih (lihat gambar 2) menunjukkan bahwa Metro TV ingin menunjukkan bahwa legitimasi ada pada Presiden Joko Widodo sehingga kabar tentang perombakan kabinet itu tidak sepatutnya berhembus.

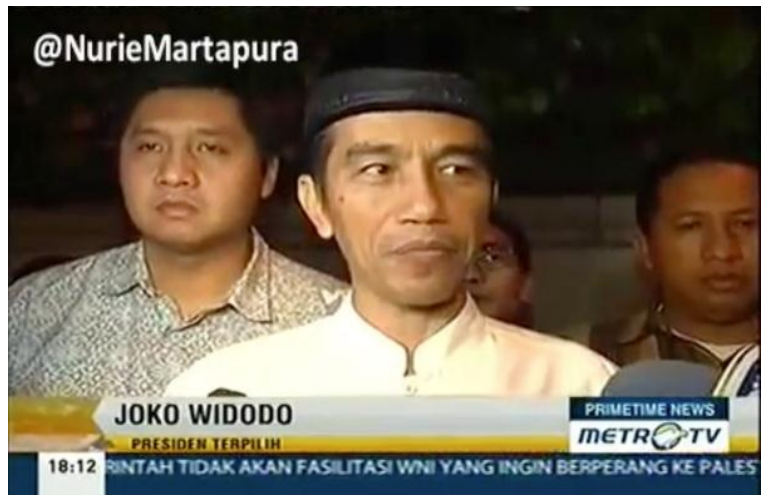

Gambar 2. Tampilan gambar Jokowi dengan graphic text: Joko Widodo Presiden Terpilih (sumber: youtube.com)

Sedangkan pada gambar 3, Metro TV menampilkan gambar dua orang menteri (salah satunya adalah Menteri Yuddy Chrisnandi) yang sedang berdialog dengan text Istana Bantah Ada Perombakan Kabinet.

Gambar ini seolah menunjukkan kepada pemirsa televisi bahwa menteri dalam Kabinet Kerja Joko Widodo JK terlihat kompak dan cakap bekerja sama. Karena itu, text Istana Bantah Ada Perombakan kabinet sepertinya menegaskan apa yang hendak dibingkai oleh Metro TV dalam berita bantahan adanya isu perombakan kabinet.

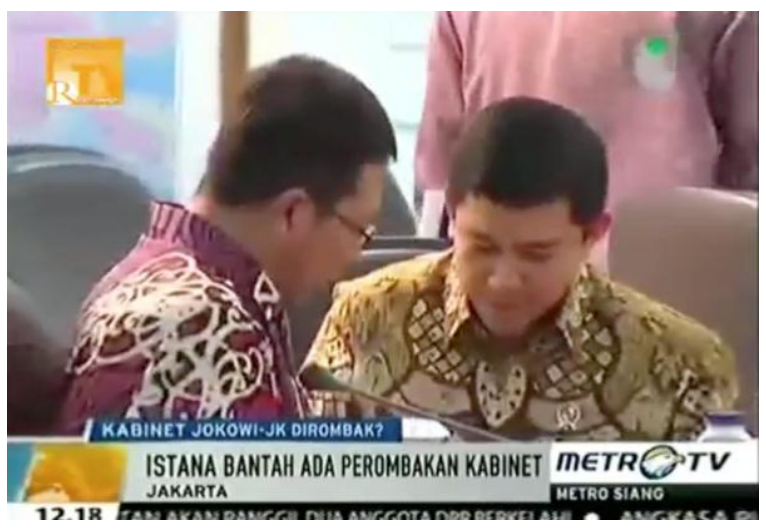

Gambar 3. Tampilan gambar menteri yang berdialog dengan graphic text: Istana Bantah Ada Perombakan Kabinet (sumber: youtube.com)

\subsection{Berita di tvOne}

1) Jokowi Menolak Rencana Pengadaan Mobil Dinas Baru Menteri Kabinet Kerja

Pada awal pemberitaan, tvOne menunjukkan dua grafis yang cukup mencolok. tvOne ingin memban- dingkan mobil dinas yang digunakan oleh para menteri KIB II (Kabinet Indonesia Bersatu jilid 2) di bawah kepemimpinan Presiden Susilo Bambang Yudhoyono (SBY) yakni Toyota Crown Royal Saloon dengan mobil dinas yang diusulkan untuk para menteri di bawah kepemimpinan Presiden Joko Widodo.

Grafis yang pertama kali dimunculkan adalah tentang mobil Toyota Crown Royal Saloon. Sedangkan grafis berikutnya adalah mobil Mercedes Benz New S 300 $\mathrm{L}$ yang disebut-sebut sebagai calon mobil dinas para menteri kabinet Joko Widodo - Jusuf Kalla.

Ada yang cukup menarik dari grafis tersebut. Pada grafis Mercedes Benz ditunjukkan spesifikasi berikut harga secara lengkap, yakni 1,8 miliar rupiah. Namun pada grafis Toyota Crown hanya ada merek dan tipe saja. Sepertinya tvOne ingin menutup bahwa harga mobil Toyota Crown Royal Saloon ini harganya pun tidak murah. Menurut Suprapto dalam viva.co.id (6 Januari 2010), harga Toyota Crown Royal Saloon mencapai harga 1,3 miliar rupiah sesuai kisaran yang diberikan oleh Indonesia Corruption Watch (ICW). Berita ini membingkai pemerintahan Joko Widodo yang dianggap tidak pro rakyat karena memilih mobil dinas yang berharga miliaran rupiah.

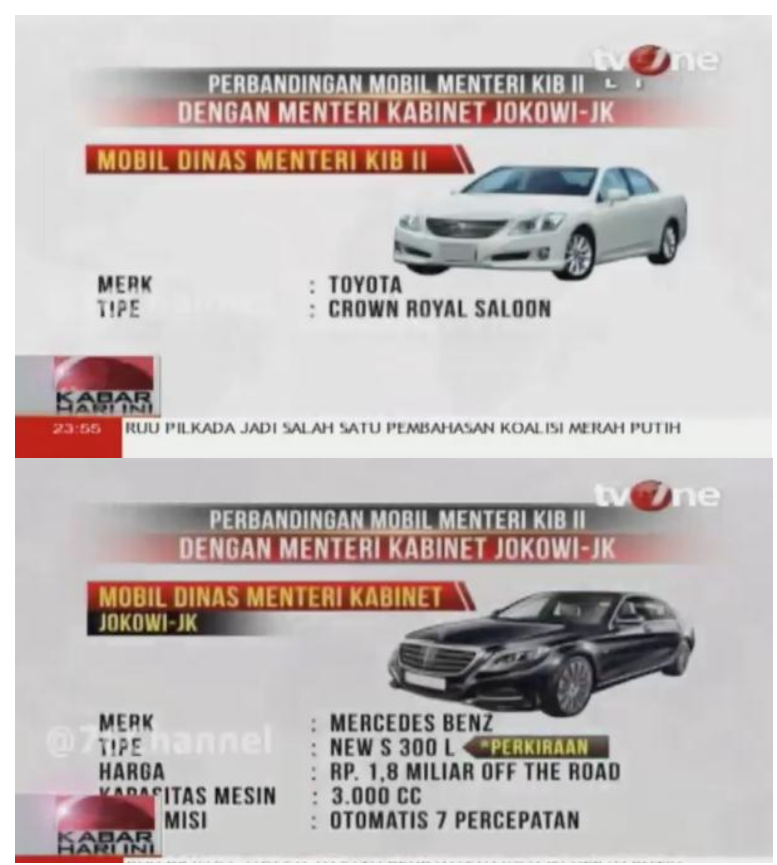

Gambar 4. Grafis gambar mobil Toyota Crown Royal Saloon dan Mercedes Benz New S 300 L (sumber: youtube.com)

Pada akhir pemberitaan, pembingkaian terhadap kebijakan sosok JokoWidodo sebagai presiden yang tidak pro rakyat makin terlihat dengan adanya 
pembahasan pemilihan mobil dinas bagi pejabat di Malaysia. Dengan perangkat exemplaar, tvOne seolah ingin menunjukkan bahwa sebenarnya pejabat Indonesia perlu meniru pejabat Malaysia yang menggunakan mobil dinas pabrikan lokal, yakni mobil Proton, yang telah go international.

Dengan perangkat depiction, berita ini seperti menunjukkan kepada pemirsa bahwa pemerintah Joko Widodo harus lebih pro rakyat dengan tidak menguras anggaran.

\section{2) Kabinet Jokowi Tersandera Parpol}

Terkait dengan pemberitaan pemilihan menteri yang akan membantu Joko Widodo dalam kabinetnya, tvOne telah membingkai bahwa Presiden Joko Widodo tidak bijak dalam pemilihan menteri. Presiden Joko Widodo dianggap tidak konsisten dalam memberikan pernyataan terkait pemilihan calon menteri.

Usai diumumkan, gelombang kritikan pun menghampiri kebijakan mantan Wali Kota Solo tersebut. Perampingan kabinet yang digembar gemborkan sejak awal, tak terjadi.... Koalisi tanpa syarat $K=$ Jokowi tak ada artinya. Jokowi dinilai tak konsisten.

Ketidakkonsistensian sosok Joko Widodo sebagai presiden itulah yang dibingkai oleh tvOne. Pada layar juga tertulis text: Presiden Terpilih Harus Konsisten (gambar 5) dan Kabinet Jokowi masih gemuk (Gambar 6) menegaskan apa yang menjadi janji Joko Widodo sebagai presiden dalam menentukan calon menteri dalam kabinetnya tidak konsisten.

Menurut tvOne hal ini disebabkan Joko Widodo sudah berjanji memilih menteri tidak berasal dari kalangan partai politik serta tidak berjumlah banyak.

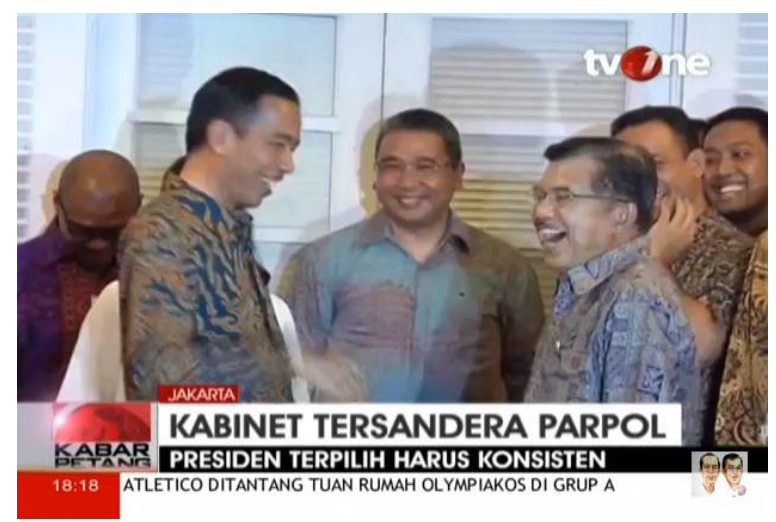

Gambar 5. Text: Presiden terpilih harus konsisten (sumber: youtube.com)

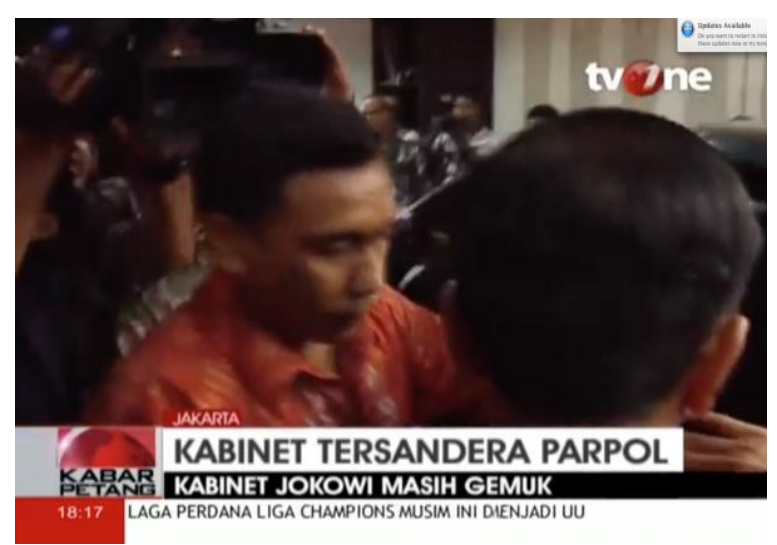

Gambar 6. Text: Kabinet Jokowi masih gemuk (sumber: youtube.com)

\section{KESIMPULAN}

Tak dapat dipungkiri, bahwa intervensi pemilik modal terlihat sangat vulgar sebagaimana sebuah riset yang telah dilakukan oleh Dewan Pers, Perkumpulan Masyarakat Peduli Media, PR2Media dan Remotivi pada tahun 2013 sebagaimana telah disampaikan oleh Ashadi Siregar dalam Wicaksono (2015, hal. 3). Terlebih lagi jika pemilik modal media massa tersebut juga merupakan pimpinan partai politik. Kecenderungan tidak bisa netral dalam pemberitaan seperti tidak terelakkan lagi.

Seperti halnya yang terjadi pada Metro TV. Pemiliknya adalah Surya Paloh yang merupakan pendiri sekaligus pemimpin Partai Nasional Demokrat yang memang pada pemilihan presiden tahun 2014 berpihak pada pasangan Joko Widodo dan Jusuf Kalla.

Sebaliknya, tvOne dimiliki oleh keluarga Aburizal Bakrie yang merupakan pimpinan Partai Golkar yang saat pemilihan presiden menunjukkan keberpihakan pada pasangan Prabowo Subianto dan Hatta Rajasa.

Karenanya, dari berita-berita yang dianalisis, peneliti menyimpulkan bingkai pemberitaan tentang Joko Widodo dalam kaitan dengan Kabinet Kerja yang dipimpinnya adalah sebagai berikut:

\begin{tabular}{c|c}
\hline MetroTV & TVOne \\
\hline Jokowi dibingkai & Jokowi dibingkai \\
sebagai presiden yang & sebagai presiden yang \\
bijak dan berprinsip & tidak konsisten dalam \\
dalam memilih dan & pemilihan calon menteri \\
memilah anggota & serta tidak pro rakyat \\
kabinet & dalam menjalankan \\
& kinerja kabinetnya \\
\hline
\end{tabular}


Di sini, Metro TV sebagai media yang dimiliki oleh Surya Paloh dengan Partasi Nasional Demokrat yang berada dalam naungan Koalisi Indonesia Hebat $(\mathrm{KIH})$, membingkai sosok Joko Widodo sebagai presiden yang bijak dan berprinsip. Hal ini menunjukkan dukungan Metro TV pada kepemimpinan Joko Widodo. Seperti yang diungkapkan oleh Subiakto dan Ida (2012, hal. 110-111), kekuatiran tentang kebebasan pers akan terhegemoni oleh kepentingan elite menyebabkan media yang tidak dapat mengontrol pemerintah atau kehilangan fungsinya sebagai watchdog.

Metro TV telah membingkai Joko Widodo sebagai presiden dengan sangat positif, yakni dengan menunjukkan kebijakan dan prinsip. Sebaliknya, tvOne membingkai Joko Widodo sebagai presiden yang tidak konsisten dan tidak pro rakyat sehingga sosok Joko Widodo menjadi negatif di mata masyarakat.

Hal seperti ini yang perlu diwaspadai oleh media massa karena bagaimana pun media masssa membutuhkan independensi dalam pewartaannya agar dapat menjalankan fungsi kontrol sosial. Sangat disayangkan, kedua stasiun televisi swasta ini masih arogan dalam menentukan bingkai pemberitaan yang disebabkan hegemoni kepentingan elite, yakni para pemilik modal yang bertarung dalam kancah politik praktis di tanah air.

\section{DAFTAR PUSTAKA}

Aburizal Bakrie. www.profil.merdeka.com, akses 13 November 2015.

Anggota DPR: Ardi Bakrie Ubah tvOne Jadi Obor Rakyat. (2014, Juli 4). Tribunnews.com.

Harsono, Andreas. (2010). 'A9ama' Saya adalah Jurnalisme. Yogyakarta: Kanisius.
Harahap, Machyudi Agung. (2013). Kapitalisme Media: ekonomi, politik, berita dan diskursus televisi. Jakarta: Aura Pustaka.

Ishwara, Luwi. (2005). Catatan-catatan Jurnalisme Dasar. Jakarta: Kompas.

Istana Bantah Adanya Perombakan Kabinet JokowiJK. (2015, April 9). Diperoleh dari https://www. youtube.com/watch?v=R-1krc-QU38.

Itule, Bruce. D dan Anderson, Douglas.A. (2000). News Writing and Reporting for Today's Media 5th edition. Singapore: McGraw-Hill Book Co.

Kabinet Jokowi Tersandera Parpol. (2014, September 16). Diperoleh dari https://www.youtube.com/ watch? $\mathrm{v}=\mathrm{t} 0 \mathrm{kRjC}-\mathrm{HgdU}$.

Mencher, Melvin. (2000). News Reporting and Writing 8th edition. Singapore: McGraw-Hill Book Co.

Prabowo Guruh Soekarno Putra Menilai Jokowi Belum Siap Menjadi Calon Presiden Republik Indonesia. (2014, Juni 10). Diperoleh dari https://www.youtube.com/watch?v=_1W_V1k8 BPY.

Subiakto, Henry dan Rachmah Ida. (2012). Komunikasi Politik, Media dan Demokrasi. Jakarta: Kencana.

Suprapto, Hadi. (2010). Mengapa Crown Royal Saloon Bisa Rp 1 Miliar. Viva.co.id, 6 Januari 2010. Akses 18 November 2015.

tvOne dan ANTV Kantongi Belanja Modal Rp 600 Miliar. (2015, April 18). cnnindonesia.com.

Wicaksono, Agung Pambudi. (2015). Media Terpenjara: Bayang-bayang pemilik dalam Pemberitaan Pemilu 2014.

Wulandari, Retno. (2014). Media Darling Ala Jokowi: Menjadi Sosok yang Disukai Media. Jakarta: Gramedia. 